\title{
STUDY HABITS OF ISPSC LABORATORY HIGH SCHOOL STUDENTS ITS RELATION TO THEIR MATHEMATICS ACHIEVEMENT
}

\author{
TESSIE. L DELA CRUZ
}

Ilocos Sur Polytechnic State College, South Cluster Campus, Tagudin, Ilocos Sur, Philippines, Asia

\begin{abstract}
The study determined the study habits of ISPSC, Laboratory High School students its relation to their Mathematics achievement.

Descriptive method of research using questionnaire, documentary analysis, interview, and observations aimed at knowing the profile, Mathematics achievement, level of study habits of the respondents and its significance to them.

Majority of the respondents were females, belonged to families with 4-6 children, parents were college graduates, farmers and housekeepers with an estimated income of Php5001-10,000 and Php 10, 0001-above.

Mathematics achievement of the LHS students was average; the level of study habits was moderately favorable, significant relationships existed on the profile and Mathematics achievement, likewise the study habits and Mathematics achievements of students.

Developing students' study habit formation teachers should capitalize on the students' strengths and work on their weaknesses by preparing activities that match their cognitive and periods for independent learning must be utilized properly to increase Mathematics achievement.

KEYWORDS: Study Habits \& Mathematics Achievement
\end{abstract}

Received: Feb 22, 2018; Accepted: Mar 15, 2018; Published: Apr 13, 2018; Paper Id.: IJESRAPR2018015

\section{INTRODUCTION}

Habits are usually the things done automatically. People say that habits are hard to break. The right kind of habit must be developed. With the exposure of the students to different technologies like computers and exposure to the environment, one develops many habits and study habits are far beyond.

Under the K-12 curriculum, Mathematics is one of the major subjects which deal primarily with numbers. Studying Mathematics may be difficult to achieve by the students. One can succeed in any endeavour if he has the ability or courage to face difficulties. Poor performance in Mathematics is a handicapped and major cause of failure in school. It really takes a good study habit to be well versed in Mathematics or at least to improve academic achievement in Mathematics.

Most authors claimed that poor study habits are the prime factor of scholastic failure. The common observations of teachers on their students are ineffective study habits which cause scholastic failures. Due to this, students even find difficulty in their academic work that results to lower mark. Such lamentable situation is reflective of students' poor performance in different academic areas such as mathematical, scientific and verbal reasoning. In general, there is a decline in the academic performance of students and graduates (Sario, 2011). 
To improve scholastic achievements, learning skills and good study habits will help a lot. The teachers are great factors to develop the students' study habits. They should give their abundant time and attention to their respective students, teach them innovatively and encourage them.

Learning skills and good study habits help students to improve their academic achievements. Good study habits are important because they help students get more knowledge. It is not a matter of how much or how many they have studied but how well they have studied.

Effective study habits acquired in school are lifetime and to a very appreciable degree, the influence of a person's achievements. Good study habits are crucial to success in the academy. Scheduling the time, having the appropriate place to study, and learning how to study alone or with other people are all habit-forming ((Philande, 2011). Establishing good study habits ensures the students having a successful start in his academic endeavours specifically Mathematics.

Through the years that the researcher has been a teacher in Mathematics for Grade 8 and Head of the Laboratory High School, she observed that most of the students have poor study habits causing low academic achievements. The improvement of the study habits of ISPSC, Laboratory High School its relation to their Mathematics achievement is deemed necessary. It is along this parameter that the study is conceived.

The result of this study serves as a benchmark to top management to continue staff development program for Mathematics, with emphasis not only on mastery of subject matter and methodology, but also to a better understanding of how students learn, and the factors that affect learning. To the teachers, identification of the salient factors affecting students' Mathematics achievement may awaken them in this subject to the situation which may enhance learning as well as factors that may affect learning. To the teachers, identification of the salient factors affecting students Mathematics achievement may awaken them in this subject to situation which may enhance learning as well as factors that may affect performance negatively. In this way teachers may adopt challenging motivations, utilizes functional visual aids so that students' attitudes toward Mathematics be improved and more importantly be more understanding of individual differences among students. Moreover, vital information from this study may also be of value to the guidance counselors who assist students with problem-related academic achievements. To the parent's result of this study is useful for they are the most concerned in the academic achievements. To the parents, the result of this study is useful for they are the most concerned in the academic achievement of the children. They should look into the needs of their children and encourage them to attain a high level of academic achievements, particularly in Mathematics. This study is also important to those students who perform well academically for they may be able to maintain their level of academic achievements throughout their subjects. For the underachievers, knowledge of the aforementioned factors that affect academic achievement may consider them as challenges to achieve better academic performance. The researcher herself, as the Head of the Laboratory High School and as a Mathematics teacher in Grade 8 is concerned with the observable study habits of the Laboratory High School students and its relation to Mathematics achievement. Further, the result of this study is a benchmark in the proper planning or utilization of independent learning periods. A similar study is undertaken by other research enthusiasts to improve instruction.

Bruner's Constructivist Theory describes the role of cognition (knowing) to determine and predict the behavioral pattern of an individual. He introduced the ideas of readiness for learning. Bruner believed that any subject could be taught at any stage of development in a way that fits the child's cognitive abilities. This feature specifically states the experiences which move the learner toward a love of learning in general, or of learning something in particular (Corpuz, 2007). 
Acido (2010) confirms an obvious observation that students' interests in things that he needs to learn to determine his acquisition of certain skills or abilities. The following indicators of good study habits among students are organized notes, lessons and materials having a regular time and place for studying lessons, making decisions about priorities concerning time and goals, good parental models and personal responsibility for what one does or does not do.

The study was conducted to determine the study habits of the Ilocos Sur Polytechnic College, Laboratory High School students and its relation to their Mathematics achievement.

Specifically, it aimed to determine:

- Profile of respondents along: sex, parents' educational attainment, occupation and estimated monthly income, number of children;

- Mathematics achievement of respondents;

- Level of study habits of respondents;

- Significant relationship with the profile of respondents and their Mathematics achievement;

- Significant relationship between the study habits and their Mathematics achievement.

Further, this study was conducted school year 2014-2015 at the ISPSC Laboratory High School, Tagudin, Ilocos Sur.

\section{METHODOLOGY}

This study was conducted to determine the relationship between study habits of the LHS students its relation to their Mathematics achievements. The descriptive method of research was used with the questionnaire adopted from the research study of Gumallaoi (2012), as the main tool in gathering data. The researcher conducted an interview with the LHS students to obtain first-hand information. This information was supplemented by the data gathered from the questionnaire. Aside from the questionnaire, the documentary analysis was used to counter check some of the responses of the students to the questionnaire, especially the final rating of students in Mathematics and to obtain additional data essential to the study.

Frequency and percentage were used to determine the profile of the respondents.

The grade point average, which is arbitrarily taken from the existing grading system of the K-12 curriculum was used in determining the Mathematics achievement of the LHS students of which their final ratings were considered.

Table

\begin{tabular}{|l|l|}
\hline \multicolumn{1}{|c|}{ Grade Point Average } & \multicolumn{1}{c|}{ Descriptive Rating } \\
\hline 90 above & Advance (A) \\
\hline $85-89$ & Proficient (P) \\
\hline $80-84$ & Approaching Proficiency (AP) \\
\hline $75-79$ & Development (D) \\
\hline 74 below & Beginning (B) \\
\hline
\end{tabular}

Weighted mean was used to determine the level of the study habits of the LHS students. The following scales were used. 
Table

\begin{tabular}{|c|c|l|}
\hline Point Value & Range & \multicolumn{1}{c|}{ Descriptive Equivalent } \\
\hline 5 & $4.20-5.00$ & Very Much Favorable (VMF)/Always \\
\hline 4 & $3.40-4.19$ & Favorable (F)/Oftentimes \\
\hline 3 & $2.60-3.39$ & Moderately Favorable (MF) Sometimes \\
\hline 2 & $1.80-2.50$ & Fairly Favorable (FF)/Seldom \\
\hline 1 & $1.00-1.79$ & Not Favorable (NF)/Never \\
\hline
\end{tabular}

For the relationship between the profile of the respondents and their Mathematics achievements likewise the relationship between the study habits of the respondents and their Mathematics achievements, the correlation was used.

Table

\begin{tabular}{|c|c|}
\hline Range & Strength of Association \\
\hline $\pm 0.1- \pm 0.3$ & Weak \\
\hline $\pm 0.31- \pm 0.3$ & Moderate \\
\hline $\pm 0.51- \pm 0.1$ & Strong \\
\hline
\end{tabular}

\section{RESULTS AND DISCUSSIONS}

Profile of Respondents

Sex

As reflected in table 1.a, the female respondents outnumbered the male respondents.

Table 1(a): The Female Respondents Outnumbered The Male Respondents

\begin{tabular}{|l|c|c|}
\hline \multicolumn{1}{|c|}{ Sex } & Frequency & Percentage \\
\hline Male & 62 & 33.51 \\
\hline Female & 123 & 66.49 \\
\hline Total & $\mathbf{1 8 5}$ & $\mathbf{1 0 0 . 0 0}$ \\
\hline
\end{tabular}

The findings imply that the majority of the respondents were females. This might be due to the fact that females have dominated the males in terms of population. (Fabro, 2009)

\section{Parents' Educational Attainment}

Table 1.b presents the parents' educational attainment which includes father's educational attainment and mother's educational attainment.

Table 1(b): Parents' Educational Attainment

\begin{tabular}{|l|c|c|c|c|}
\hline $\begin{array}{c}\text { Parents' Educational } \\
\text { Attainment }\end{array}$ & $\begin{array}{c}\text { Frequency } \\
\text { (Father) }\end{array}$ & Percentage & $\begin{array}{c}\text { Frequency } \\
\text { (Mother) }\end{array}$ & Percentage \\
\hline $\begin{array}{l}\text { Elementary } \\
\text { Undergraduate }\end{array}$ & 1 & 54 & 1 & 54 \\
\hline Elementary Graduate & 10 & 5.41 & 7 & 3.78 \\
\hline $\begin{array}{l}\text { High School } \\
\text { Undergraduate }\end{array}$ & 31 & 16.76 & 13 & 7.03 \\
\hline High School Graduate & 33 & 17.84 & 56 & 30.27 \\
\hline College Level & 32 & 17.29 & 29 & 15.68 \\
\hline College Graduate & 77 & 41.62 & 79 & 42.70 \\
\hline Others (Vocational) & 1 & 54 & & \\
\hline \multicolumn{1}{|c|}{ Total } & $\mathbf{1 8 5}$ & $\mathbf{1 0 0 . 0 0}$ & $\mathbf{1 8 5}$ & $\mathbf{1 0 0 . 0 0}$ \\
\hline
\end{tabular}


The majority of the respondents' parents finished college. These findings imply that education is a privilege to all Filipinos as well as the existing program of the government "Education for all" (De Leon, 2009).

\section{Parents' Occupation}

Table 1.c manifests parents' occupation: fathers' occupation and mothers' occupation

Table 1(c): Parents' Occupation

\begin{tabular}{|l|c|c|l|c|c|}
\hline $\begin{array}{l}\text { Parents' Occupation } \\
\text { (Father) }\end{array}$ & Frequency & Percentage & $\begin{array}{c}\text { Parents' Occupation } \\
\text { (Mother) }\end{array}$ & Frequency & Percentage \\
\hline Agriculture/Farming & 65 & 35.14 & Housekeeping & 100 & 54.05 \\
\hline Businessman & 23 & 12.43 & Businesswoman & 18 & 9.73 \\
\hline Teaching & 11 & 5.95 & Teaching & 28 & 15.14 \\
\hline $\begin{array}{l}\text { Government } \\
\text { Employee }\end{array}$ & 14 & 7.57 & $\begin{array}{l}\text { Government } \\
\text { Employee }\end{array}$ & 13 & 7.03 \\
\hline $\begin{array}{l}\text { Others (specify) } \\
\text { OFW }\end{array}$ & 18 & 9.73 & $\begin{array}{l}\text { Others (specify) } \\
\text { OFW }\end{array}$ & 18 & 9.73 \\
\hline Nurse & 1 & .54 & Nurse & 2 & 1.08 \\
\hline Laborer & 35 & 18.92 & Dressmaker & 3 & 1.63 \\
\hline Baker & 2 & 1.08 & Midwife & 2 & 1.08 \\
\hline Optician & 1 & .54 & Optometrist & 1 & .54 \\
\hline Pastor & 1 & .54 & & & \\
\hline Carpenter & 14 & 7.57 & & & \\
\hline \multicolumn{1}{r|}{ Total } & $\mathbf{1 8 5}$ & $\mathbf{1 0 0}$ & & & \\
\hline
\end{tabular}

Most of the respondents' fathers were farmers. The finding implies that the Philippines is an agricultural country. Further, it indicates that most barangays of Tagudin are an agricultural place wherein children of farmers are obliged to work on the farms during vacation or weekends. However, the majority of the respondents' mothers were also housekeepers. The finding implies that the mothers stay in their homes to serve their family members by doing household chores. Valdez (2012) further stated in her study that most of the respondents' mothers were housekeepers due to the fact that these women are not educated enough and they do not meet the required qualifications for the white and blue collar jobs.

\section{Number of Children in the Family}

Table 1(d): Shows the Number of Children in the Family

\begin{tabular}{|c|c|c|}
\hline Number of Children & Frequency & Percentage \\
\hline $1-3$ & 47 & 25.41 \\
\hline $4-6$ & 135 & 72.97 \\
\hline $7-9$ & 2 & 1.08 \\
\hline 10 above & 1 & .54 \\
\hline Total & $\mathbf{1 8 5}$ & $\mathbf{1 0 0}$ \\
\hline
\end{tabular}

Majority of the respondents belonged to a family with 4-6 children. The findings imply that most of the respondents belonged to large families and that this can be traced from the Ilocano families' belief that having a greater number of children makes the family happier (Valdez, 2012). 
Estimated Monthly Income

Table 1(e): Manifests the Respondents' Estimated

Monthly Income of Parents

\begin{tabular}{|c|c|c|}
\hline Estimated Monthly Income & Frequency & Percentage \\
\hline $5,001-10,000$ & 93 & 50.27 \\
\hline 10,000 above & 92 & 49.73 \\
\hline Total & $\mathbf{1 8 5}$ & $\mathbf{1 0 0}$ \\
\hline
\end{tabular}

The result shows that most of the respondent's monthly income were average, just enough to augment the basic needs of the family members. The findings imply that there is a need to motivate the students to study hard and continue their higher education for it is believed that education is the solution for a better employment and better way of living. Such a finding concurs with the findings of Sario (2011) when he revealed that most of the respondents' families generally belonged to the lower-middle class of the economic sectors of our society.

Mathematics Achievement of the Respondents

Table 2: Shows the Mathematics Achievement of the LHS Students

\begin{tabular}{|c|c|c|l|}
\hline Grade Point Average & Frequency & Percentage & \multicolumn{1}{|c|}{ Descriptive Equivalent } \\
\hline 90 above & 27 & 14.59 & Advance (A) \\
\hline $85-89$ & 68 & 36.76 & Proficient (P) \\
\hline $80-84$ & 78 & 42.16 & Approaching Proficiency (AP) \\
\hline $75-79$ & 12 & 6.49 & Development (D) \\
\hline 74 below & & & Beginning (B) \\
\hline Total & $\mathbf{1 8 5}$ & $\mathbf{1 0 0}$ & \\
\hline
\end{tabular}

Majority of the LHS students obtained grades ranging from 80-84 described as "Approaching Proficiency". The finding implies that the Laboratory High School students do not have commendable achievements in Mathematics. The Mathematics teachers need to exert effort to find ways and means to improve the level of achievement of students in Mathematics to come up with an "Advance" rating. Teachers' commitment should be emphasized, such that they must be competent not only in their teaching, but in understanding each and every student entrusted to them.

Pilande (2011) cited that studying effectively is undoubtedly a factor in students' ability to excel in class. An average student who knows the ways and therefore of effective studying can make it to the top, and can even overcome the more intelligent ones who have never learned how to study effectively. Effective study habits among students develop the positive attitude towards schooling and preventing a waste of untapped talents and intelligences.

\section{Study Habits}

Table 3: Manifests the Level of Study Habits of the Respondents

\begin{tabular}{|l|c|l|}
\hline \multicolumn{1}{|c|}{ Indicators } & Sub-Mean Value & \multicolumn{1}{c|}{ Descriptive Equivalent } \\
\hline Where to study & 3.69 & Favorable(F) Oftentimes(O) \\
\hline When to study & 3.05 & Moderately Favorable(MF)/Sometimes(S) \\
\hline How to study & 3.15 & Moderately Favorable(MF)/Sometimes(S) \\
\hline Over All Mean & 3.29 & Moderately Favorable(MF)/Sometimes (S) \\
\hline
\end{tabular}

The result shows that the level of the study habits of the respondents is "Moderately Favorable." This finding implies that there is a need to call the attention of the concerned parents to continue guiding and supervising their children in studying and in making their assignments or homework at home. As a way of developing habit formation, Mathematics 
teachers should try to devote their attention to the students' strengths and weaknesses by preparing activities that match they are cognitive.

Gumallaoi (2012) cited in her study that students of today do not follow a definite time schedule for studying at home nor in school. She further stated that students are constant learners. It is the responsibility of the parents and teachers to encourage students to establish good study habits, to come up with expected learning outcomes. The assignment or homework should be checked and recorded to encourage students to study.

\section{Relationship Between the Profile of the Respondents and their Mathematics Achievement}

Table 4: The Relationships between the Profile of the LHS Students and Their Mathematics Achievement.

\begin{tabular}{|l|c|l|c|c|l|}
\hline \multicolumn{1}{|c|}{ Profile } & r & Interpretation & P value & Remarks & \multicolumn{1}{c|}{ Decision } \\
\hline Sex & .138 & Moderate & .062 & NS & Accept Ho \\
\hline Parents' Educational Attainment: & & & & & \\
Father & -.013 & No Correlation & .863 & NS & Accept Ho \\
Mother & .044 & No Correlation & .556 & NS & Accept Ho \\
\hline Parents' Occupation & & & & & \multirow{2}{*}{ Accept Ho } \\
Father & -.037 & No Correlation & .615 & NS & \\
Mother & .003 & No Correlation & & & \\
\hline Number of Children in the Family & $.152^{*}$ & Weak Correlation & .039 & S & Reject Ho \\
\hline Estimated Monthly Income of parents & .056 & No Correlation & .449 & NS & Accept Ho \\
\hline
\end{tabular}

Legend: Correlation is significant @.05 level (2tailed) NS=Not Significant S=Significant

The profile of the respondents shows a significant relationship in their Mathematics achievement. The number is a factor in their Mathematics achievement. All the other profiles have no significant relationships which mean that they are not contributory factors to their Mathematics achievement. Such findings reveal that due to their number in the family can affect their Mathematics achievement, the more members of the family the students receive lower marks in Mathematics. During PTA meetings class advisers should include the Mathematics achievements as one of the agenda most especially the underachievers to improve their grades and also parents are reminded of their important role in the students' development of proper studying despite their preoccupied work.

Relationship between the study habits of the Laboratory High School students and their Mathematics Achievement

The relationship between the study habits of the LHS students and their Mathematics achievement is exhibited on table 5 .

Table 5

\begin{tabular}{|c|l|c|l|}
\hline r-value & Interpretation & Remarks & Decision \\
\hline $.177^{*}$ & Strong Correlation & $\mathrm{S}$ & Reject Ho \\
\hline
\end{tabular}

Legend: Correlation is significant @ .05 level (2-tailed) S=Significant

A closer look at the table reflects that the study habit is significantly correlated with the Mathematics achievement of the LHS students. It means that the study habit of the respondents is a factor that can affect their Mathematics achievement. Mathematics teachers should help students to sustain proper attitudes in studying by inspecting their work, check their assignments or any kind of activities, having conferences with them about their progress, be meeting with some of them who have special difficulties and praise their accomplishments. The periods of independent 
learning for students must be utilized properly that the study habit of the respondents is a factor that can affect their Mathematics achievement. Mathematics teachers should help students to sustain proper attitudes in studying by inspecting their work, check their assignments or any kind of activities, having conferences with them about their progress, meeting with some of them who have special difficulties and praise their accomplishments. The periods of independent learning for students must be utilized proper giving them chances to engage in activities that will increase Mathematics achievement. Further, the involvement of the Guidance Counselors in all activities of the LHS students must be strengthened. Success in the study depends not only on one's ability and hard work, but also on his effective study habits (Montano, et.al.). Further, such finding of the study also confirms the study of Gumallaoi (2012) that there exists a significant relationship between study habits and Mathematics performance. Students who have good study habits tend to have a better understanding during the teaching-learning process.

\section{REFERENCES}

1. Acido, M. (2010). High School Students Reasoning Skills and their Study Habits and Attitudes Towards Learning: A Journal of Basic Education, pages 108-117. Retrieved at March 2, 2016.

2. Best, J.V. (1981). Research in Education. $4^{\text {th }}$ Ed. New Jersey Prentice Hall. Philippine Edition, Alemar's Book Store.

3. De Leon, H.S. (2009). The 1987 Philippine Constitution. Manila. National Book Store.

4. Fabro, G.V. (2009). Filipino Values Revisited. Manila. National Book Store, Inc.

5. Gumallaoi, J.G. (2012)."Predictors of Mathematics Performance (College Algebra) of College Freshmen at Ilocos Sur Polytechnic State College." Unpublished Master's Thesis, ISPSC, Tagudin, Ilocos Sur.

6. Montano, C. et.al. (1988). ”The Students Study Skills: How to Develop Them. Students News Journal Vol. II, No. 13.

7. Philande, D.M. (2011). "Personality Traits, Study Habits and Attitudes as Correlates of Academic Performance Among Junior High School Students.” Unpublished Master's Thesis, Pamantasan ng Lungsod ng Maynila.

8. D. Chitra et al.,, A Study on Self-Acceptance and Academic Achievement among High School Students in Vellore District, International Journal of Educational Science and Research (IJESR), Volume 7, Issue 2, March - April 2017, pp. 83-92

9. Sario, E. B. (2011).”The Study Habits of Freshman College Students of Isabela State University, Jones Campus, Second Semester 2010-2011" It's Relation to their Achievements in English. "Research Journal, Isabela State University.

10. Ulit, D. et. al. (2005). Teaching Strategies in the Elementary, Mandaluyong City: National Book Store.

11. Valdez, E.G. (2012). “Behavioral Culture of Sophomore Students of Public Secondary Schools of Sta. Cruz." Unpublished Master's Thesis, ISPSC, Tagudin, Ilocos Sur.

12. Zulueta, F.M.(2006). Principles of Teaching. Mandaluyong City: National Book Store. 